\title{
EVALUASI KEBIJAKAN SISTEM ZONASI DALAM PENERIMAAN SISWA BARU SEKOLAH MENENGAH ATAS
}

\author{
Hendrawansyah $^{1}$ dan Zamroni ${ }^{2}$ \\ ${ }^{1}$ Program Pascasarjana Universitas Negeri Yogyakarta \\ ${ }^{2}$ Fakultas Ekonomi Universitas Negeri Yogyakarta \\ email: hendrawansyah.2017@student.uny.ac.id
}

\begin{abstract}
Abstrak
Tujuan penelitian adalah untuk mengevaluasi implementasi kebijakan sistem zonasi dalam Penerimaan Peserta Didik Baru di SMA Negeri di Kota Bima, Nusa Tenggara Barat. Penelitian ini merupakan penelitian evaluasi, menggunakan pendekatan deskriptif kuantitatif dengan model goal oriented yang dikembangkan oleh Tyler. Penelitian ini melibatkan semua sekolah yang ada di SMA Negeri Kota Bima. Pengumpulan data menggunakan wawancara dan kuesioner. Hasil dari penelitian adalah sebagai berikut. Pertama, respons semua kepala sekolah terhadap implementasi kebijakan sistem zonasi sangat positif dan implementasi kebijakan sistem zonasi melalui responden siswa, orang tua, dan guru tingkat keterlaksanaannya dalam kategori tinggi/baik. Kedua, beberapa faktor yang menghambat implementasi kebijakan sistem zonasi yaitu: minimnya sosialisasi, regulasi penetapan zona yang belum jelas, tidak sejalannya pembukaan pendaftaran siswa baru antara sekolah yang berada dalam naungan Disdikbud dengan sekolah yang berada dalam naungan Depag, penyebaran guru yang belum merata, dan kurangnya episentrum hukum yang tegas. Ketiga, tujuan yang dicapai dalam Penerimaan Peserta Didik Baru yang ditinjau dari prestasi akademik siswa telah merata.
\end{abstract}

Kata kunci: kebijakan pendidikan, evaluasi berorientasi tujuan

\section{POLICY EVALUATION OF THE ZONING SYSTEM IN NEW STUDENT ADMISSION AT HIGH SCHOOL LEVEL}

\begin{abstract}
This study was aimed at evaluating the implementation of the zoning system policy in the new student admission procedure in State High Schools, Bima, West Nusa Tenggara. This study was an evaluation research, using a quantitative descriptive approach with a goal-oriented model developed by Tyler. This study involved all state high schools in Bima. The data were gathered using interviews and questionnaires. The results show that: first, the responses of all school principals to the implementation of the zoning system policies are positive and the implementation of the zoning system policies through student respondents, parents and teachers is in the high/good category. Second, several factors that hinder the implementation of the zoning system policies are lack of socialization, unclear zoning regulations, incompatible opening of new student registration between the schools within the Ministry of Education and Culture and Ministry of Religious Affairs auspices, uneven distribution of teachers, and lack of strict legal epicenters. Third, the goals of students' academic achievement obtained in new student admissions have been evenly distributed.
\end{abstract}

Keywords: educational policy, goal-oriented evaluation 


\section{PENDAHULUAN}

Sejalan dengan berkembangnya zaman, kehidupan masyarakat semakin mengalami kemajuan sehingga peran pendidikan menjadi sangat penting. Pendidikan adalah salah satu faktor utama dalam membangun sumber daya manusia dengan cara memotivasi dan mendorong manusia untuk belajar. Pendidikan merupakan bagian dari kehidupan masyarakat dan juga sebagai penunjang kehidupan masyarakat itu sendiri (Tilaar, 2001, p. 80).

Pendidikan juga sebagai investasi jangka panjang yang mempunyai nilai strategis, baik bagi kepentingan individu maupun kepentingan kelompok. Setiap manusia dapat mengembangkan potensi dirinya melalui pendidikan yang baik. Oleh sebab itu, pendidikan menjadi perlu untuk ditingkatkan secara terus menerus terutama kualitasnya demi mempersiapkan generasi penerus bangsa yang akan menjadi agen perubahan sehingga memiliki keunggulan yang kompetitif dalam tatanan kehidupan nasional maupun global.

Kualitas pendidikan menjadi tujuan utama yang harus diperjuangkan oleh seluruh elemen pendidikan sehingga dapat menghasilkan sumber daya manusia yang kreatif dalam menghadapi tantangan zaman. Terwujudnya kualitas pendidikan yang baik, sedikit tidaknya juga dipengaruhi oleh lembaga pendidikan. Lembaga pendidikan adalah suatu sarana untuk melayani konsumen berupa siswa, dan masyarakat dari berbagai bidang baik layanan dalam bentuk fisik bangunan maupun layanan berupa fasilitas yang memadai, guru yang bermutu dan profesional.

Salah satu fungsi dari pendidikan adalah menciptakan pengetahuan yang pada akhirnya di-akumulasi oleh kelompok masyarakat dan digunakan untuk mengontrol berbagai aspek kehidupan masyarakat
(Sirozi, 2010, p. 67). Oleh karena itu, jasa pendidikan sangat dibutuhkan dalam memberikan pelayanan sehingga dapat menciptakan peserta didik yang lebih baik. Alvarez dan Ruiz-Casares (1998, p. 11) menjelaskan bahwa penguatan nilainilai sosial yang baik dengan memberikan pelayanan pendidikan yang baik akan membentuk mekanisme pendidikan yang baik serta dapat menjamin pendidikan yang berkelanjutan dari pendidikan itu.

Salah satu strategi pembangunan pendidikan nasional adalah memperluas akses pendidikan yang berkualitas. Pendidikan yang berkualitas akan diperoleh pada sekolah yang berkualitas dan sekolah yang berkualitas akan menghasilkan peserta didik yang berkualitas pula (Syamsuriyanti \& Sukirno, 2018).

Pada hakikatnya pendidikan dipercaya sebagai roda penggerak mobilitas sosial yang menjadi tolak ukur bahwa peserta didik mengalami kemajuan dan kesejahteraan. Sebagaimana yang diungkapkan oleh $\mathrm{Wu}$ (2017) bahwa pendidikan merupakan roda penggerak untuk membangun mobilitas sosial. Sebagian besar manusia berusaha memperbaiki hidupnya melalui pendidikan.

Keberadaan pendidikan dapat memberikan peluang adanya peningkatan status sosial dalam meningkatkan kualitas taraf hidupnya (Seknun, 2015). Berdasarkan hasil penelitian terdapat hubungan yang kuat antara tingkat pendidikan dan kehidupan sosial masyarakat. Jika tingkat pendidikannya maju maka tingkat kehidupan sosialnya akan maju begitupun sebaliknya. Dalam hal ini, pendidikan menjadi penting untuk masa depan dan mengatasi persoalan ketidakadilan dalam pendidikan.

Dewasa ini terdapat fenomena sekolah favorit yang menjadi tujuan. Fenomena ini muncul karena ada kebijakan untuk memasuki sekolah berdasarkan hasil Nilai 
Ebtanas Murni (NEM) jenjang sekolah di bawahnya. Akibatnya, siswa yang memiliki prestasi tinggi berkumpul pada sekolah favorit. Fenomena sekolah favorit menjadikan ketimpangan prestasi diantara para siswa semakin tajam. Sekolah yang berkualitas semakin berkualitas sebaliknya sekolah yang tidak berkualitas cenderung statis.

Fenomena di atas menyentuh keadilan dalam pelayanan pendidikan. Meskipun latar belakang sosial peserta didik berbedabeda, namun mereka tetap menginginkan agar mendapatkan kedudukan dan kesempatan yang sama di dalam pendidikan. Mendapatkan pendidikan sama berarti mendapatkan pendidikan yang merata. Semua masyarakat berhak mendapatkannya tanpa membeda-bedakan status sosialnya.

Pada kenyataannya realitas pendidikan di indonesia belum terdefinisi secara merata. Sekolah yang baik didominasi oleh orang-orang kaya sedangkan orang miskin hanya berkesempatan memasuki sekolah yang mutunya kurang bagus. Oleh karena itu, sekolah yang bermutu akan semakin maju sedangkan sekolah yang tidak bermutu tidak dapat maju dan berkembang. Maka muncullah sekolah favorit dan tidak favorit. Sekolah favorit biasanya dimasuki oleh orang oleh orangorang kaya sementara sekolah yang tidak favorit biasanya dimasuki oleh orang-orang miskin. Fenomena di atas merupakan penyebab awal terjadinya stratifikasi sosial. Padahal pendidikan diharapkan dapat menghadirkan tatanan sosial yang baik dan bukan sebagai alat untuk menciptakan stratifikasi sosial (Eto, 2015, p. 50).

Dengan demikian, kesenjangan kemiskinan antargenerasi tetap berjalan. Hal tersebut merupakan ketidaksetaraan yang akan melahirkan ketimpangan di dalam pendidikan (Maloutas, Hadjiyanni, Kapella, Spyrellis, \& Vallassi, 2013).
Pendidikan sebagai sarana mobilitas hanya bisa dimasuki oleh orang-orang kaya. Oleh karena itu, pemerintah melalui kebijakan sistem zonasi memutuskan pemerataan pendidikan yang berkualitas. Selain itu pemerintah berupaya untuk menghilangkan ketimpangan yang terjadi di masyarakat mengenai sekolah favorit dan tidak favorit. Perdana (2019) mengungkapkan bahwa penerimaan peserta didik baru dengan sistem zonasi dapat memeratakan pendidikan baik dari sisi input, penyebaran, dan dapat mengilangkan pelabelan sekolah favorit dan tidak favorit. Kebijakan sistem zonasi dengan segala tantangannya telah berjalan dua tahun tetapi belum pernah dilihat di Kota Bima.

Pada Penerimaan Peserta Didik Baru (PPDB) berdasarkan Permendikbud Nomor 17 Tahun 2017 bertujuan menjamin penerimaan peserta didik baru berjalan dengan objektif, akuntabel, transparan, dan tanpa diskriminasi sehingga mendorong peningkatan akses layanan pendidikan. Sistem zonasi merupakan sistem yang diberlakukan dengan penentuan zona oleh pemerintah daerah masing-masing yang wajib menerima calon peserta didik yang berdomisili pada radius zona terdekat dari sekolah dengan persentase tertentu dari total jumlah peserta didik yang diterima. Radius zona terdekat ditetapkan oleh pemerintah daerah sesuai dengan kondisi daerah masing-masing. Pemerintah berupaya untuk melakukan pemerataan pendidikan dengan menerapkan kebijakan zonasi dalam penerimaan peserta didik baru, namun di sisi lain pada pelaksanaannya praktek kesataraan pendidikan suatu kebijakan menjadi tidak merata (Musset, 2012, p. 8).

Inspektur Kemendikbud Daryanto mengungkapkan bahwa PPDB dengan sistem zonasi menempati posisi yang tertinggi dalam laporan pengaduan masyarakat yang dikirim ke Kemendikbud. Laporan 
tersebut berjumlah 240 yang diterima dalam kurun waktu Juni-Juli 2017 dan kurang lebih 170 di antaranya merupakan pengaduan terkait masalah PPDB yang dilandaskan pada sistem zonasi. Terjadinya masalah di dalam pelaksanaan kebijakan sistem zonasi disebabkan karena minimnya sosialisasi dan ketidaksiapan dari peserta didik dan orang tua di dalam menerima perubahan sistem pendidikan (Adiputra, Karsidi, \& Haryono, 2019). Terbatasnya waktu di dalam melakukan sosialisasi dan kekurangpahaman terhadap mekanisme pelaksanaan PPDB, serta standar pendidikan yang belum merata merupakan hambatan dalam pelaksanaan sistem zonasi (Bintoro, 2018).

Berdasarkan wawancara dengan beberapa guru yang ada di SMA Negeri Kota Bima bahwa dengan adanya proses PPDB melalui sistem zonasi menimbulkan masalah baru. Pertama, peserta didik di Kota Bima tidak dapat berkompetisi lagi untuk masuk ke SMA kecuali dalam sistem zonasi. Kedua, rata-rata prestasi didik menurun karena siswa berprestasi terbagi di seluruh zona. Walaupun peserta didik memiliki nilai rata-rata ujian nasional yang rendah mau tidak mau sekolah harus menerima kecuali siswa yang mempunyai nilai yang rendah sekali di bawah standar. Ketiga, dengan adanya sistem zonasi tingkat disiplin belajar menurun dan pelanggaran tata tertib meningkat.

Mekanisme yang kurang baik di dalam pelaksanaan sistem pendidikan memberikan efek kurang baik pada keberlangsungan pendidikan peserta didik. Akibatnya, timbul ketidaksetaraan di dalam mekanisme pendidikan yang dapat menyebabkan segregasi dan pengacakan penerimaan peserta didik di sekolah yang kurang baik (Narayan, Saavedra-Chanduvi, \& Tiwari, 2013, p. 15). Dengan sistem zonasi dapat menyebabkan calon peserta didik yang bernilai tinggi tidak dapat diterima di sekolah yang diinginkan karena berdomisili jauh dari sekolah tersebut. Calon peserta didik merasa kesulitan untuk masuk ke sekolah terbaik karena berada di zona yang berbeda yang padat populasinya, sehingga terpaksa mendaftar ke sekolah di zona terdekatnya yang mutunya kurang baik begitipun sebaliknya. Berdasarkan masalah di atas maka tujuan dari penelitian ini, untuk mengevaluasi kebijakan sistem zonasi dalam PPDB di SMA Negeri Kota Bima.

\section{METODE}

Jenis penelitian ini merupakan penelitian evaluasi kebijakan. Penelitian ini menggunakan wawancara sebagai data kualitatif dan kuesioner sebagai data kuantitatif. Penelitian ini melibatkan 5 sekolah yang ada di Kota Bima yang meliputi SMA Negeri 1 Kota Bima, SMA Negeri 2 Kota Bima, SMA Negeri 3 Kota Bima, SMA Negeri 4 Kota Bima, dan SMA Negeri 5 Kota Bima dengan sampel siswa, orang tua siswa, dan guru.

Teknik pengambilan sampel menggunakan proportionate stratified random sampling menggunakan rumus Slovin dengan toleransi kesalahan sebesar 0,05. Instrumen yang digunakan yaitu wawancara, kuesioner, dan nilai-nilai rata-rata Ujian Nasional SMP yang mendaftar di SMA Negeri Kota Bima.

Data kualitatif yang berupa wawancara dianalisis menggunakan cara yang dikemukakan oleh Miles dan Huberman (1994) yang terdiri dari tiga tahapan yaitu reduksi data, penyajian data, dan penarikan kesimpulan. Data kuantitatif dianalisis menggunakan analisis deskriptif kuantitatif. Instrumen penelitian berguna untuk memperoleh data numerikal. Tabulasi data untuk masing-masing komponen dilakukan terhadap skor yang diperoleh dengan menggunakan bantuan Ms. Excel 
atau SPSS sehingga diperoleh nilai ratarata, modus, rentang, nilai maksimum dan minimum atau mendeskripsikan data dalam angka dan presentase untuk setiap komponen yang ada dalam standar penelitian, kemudian diterjemahkan untuk melahirkan suatu kesimpulan. Teknik analisis data yang digunakan mengacu pada rumus yang dikembangkan oleh Azwar (2018, p. 148)

\section{HASIL PENELITIAN DAN PEMBAHASAN}

Penelitian evaluasi mengenai implementasi kebijakan sistem zonasi dalam PPDB di Kota Bima menggunakn model goal oriented evaluation yang diperoleh melalui wawancara, kuesioner yang disusun berdasarkan indikatorindikator yang disesuaikan dengan Peraturan Pemerintah Nomor 17 Tahun 2017 tentang Implementasi Kebijakan Zonasi. Satu hal lain yang dilihat dari penerimaan peserta didik melalui sistem zonasi yang menjadi produk adalah prestasi akademik siswa melalui Ujian Nasional (UN) SMP siswa.

Berikut ini dipaparkan hasil wawancara dengan kepala sekolah mengenai implementasi kebijakan zonasi dalam PPDBdi SMA Negeri Kota terkait implementasi kebijakan zonasi dalam PPDB oleh pemerintah yang mengacu pada Peraturan Pemerintah Nomor 17 Tahun 2017 sudah baik dengan tujuan pemerataan pendidikan. Selain dapat memudahkan aksebilitas siswa menuju ke sekolah juga dari segi ekonomi dapat menghemat biaya. Dengan adanya sistem zonasi membuat orang tua lebih mudah memantau perkembangan anaknya selama menempuh pendidikan di sekolah karena jarak antara rumah dan sekolah sangat dekat.

Untuk sosialisasi sendiri terkait zonasi telah dilakukan, baik kepada siswa, orang tua siswa maupun guru di sekolah. Orang tua siswa di undang ke sekolah, bahkan ada forum lain juga telah memberikan pemahaman yang sekiranya menjadi alternatif dalam PPDB dengan sistem zonasi. Namun, yang menjadi kesulitan atau kendalanya adalah perspektif orang tua terhadap sekolah unggulan. Walaupun ada sekolah yang terdekat dengan rumah, akan tetapi tetap ada orang tua yang memaksakan kehendak agar anaknya dapat diterima di sekolah unggulan.

Hal lain yang menjadi kendala adalah karena beberapa siswa berprestasi yang berada di luar zona memiliki kuota yang sedikit sehingga terbatas untuk mendaftar ke sekolah. Secara umum setelah melakukan pemantauan dan pengawasan terhadap pelaksanaaan sistem zonasi dalam penerimaan siswa baru tujuan yang diharapkan telah berjalan dengan baik. Namun, masih ada yang perlu diperhatikan terutama episentrum hukum yang belum cukup kuat di dalam pengawasan dalam PPDB di sekolah. Harapan yang lain, kuota bagi siswa yang berprestasi dapat diperbesar sehinggga siswa yang berada di luar zona termasuk yang berada di luar kota dapat masuk ke sekolah yang diinginkan. Pelaksanaan sistem zonasi dalam PPDB tidak ada masalah yang signifikan dihadapi oleh sekolah.

Di Kota Bima sendiri mempunyai dua kriteria sekolah yaitu sekolah yang berada dalam naungan pemerintah seperti SMAN dan SMK dan sekolah yang berada dalam naungan Departemen Agama yaitu Madrasah Aliyah Negeri (MAN). Sekolah yang menerapkan sistem zonasi hanyalah Sekolah SMA Negeri sedangkan SMK dan MAN tidak menerapkan sistem zonasi. Saat penerimaan siswa baru, sekolah SMK dan MAN mempunyai peluang menerima siswa baru dalam jumlah yang besar karena melakukan pembukaan pendaftaran siswa baru terlebih dahulu dari pada SMA. Akibatnya, SMA ini menjadi pilihan ketiga 
untuk mendaftar dan kuota siswa yang di terima di SMA menjadi terbatas. Dalam hal ini, tentu tidak memberikan kesempatan yang sama di dalam berkompetisi kepada sekolah-sekolah yang ada di Kota Bima. Efek lainnya siswa menumpuk pada satu sekolah tertentu sehingga menimbulkan ketidakmerataaan. Sekolah yang berada dalam naungan pemerintah dan sekolah yang berada dalam naungan Departemen Agama harusnya berjalan bersama dalam melaksanakan pembukaan penerimaan siswa baru di Kota Bima.

Menurut Kepala Sekolah SMA Negeri 3 Kota Bima kebijakan sistem zonasi dalam PPDB memberlakukan kebijakan bersekolah di area tempat tinggal dapat menciptakan keadilan yang layak demi adanya perubahan yang positif dalam dunia pendidikan. Penerapan sistem zonasi dalam penerimaan siswa baru juga dapat mengurangi intensitas gangguan dari luar yang dapat mengganggu performa akademik siswa. Namun, sistem zonasi dalam praktiknya di lapangan mengalami hambatan. Kesulitan yang di alami oleh SMA Negeri 3 Kota Bima sama halnya dengan yang dialami oleh SMA Negeri 2 Kota Bima.

Sekolah yang berada dalam naungan Dinas Pendidikan dan yang berada dalam naungan Departemen Agama tidak membuka pendaftaran penerimaan siswa baru dalam waktu yang bersamaan. Harapannya, di dalam penerimaan siswa baru dengan sistem zona ini seharusnya dilakukan secara serentak antara departemen agama dengan dengan Dinas Pendidikan dan Kebudayaan sehingga penerimaan siswa baru menjadi merata.

Kepala Sekolah SMA Negeri 4 Kota Bima berpendapat bahwa sebelum diterapkannya kebijakan zonasi telah dilakukan sosialisasi karena tanpa sosialisasi orang tua tidak akan mengetahui bahwa sistem PPDB telah berubah. Jadi jauh-jauh hari sudah kami sosialisasikan. Kami sebagai guru dipanggil oleh pihak provinsi, setelah itu dikomunikasikan kepada orang tua siswa maupun calon siswa.

Penerapan sistem zonasi dalam PPDB di Kota Bima yang dicanangkan oleh pemerintah dengan niat memeratakan pendidikan sebagai upaya mendekatkan rumah siswa dengan sekolah merupakan kabar yang sangat baik. Namun, yang menjadi kesulitannya adalah pemetaan zona antara rumah tinggal siswa dengan sekolah, tetapi terkadang ada juga orang tua siswa yang memaksakan kehendak.

Tujuan pemerintah adalah pemerataaan. Namun hal tersebut, belum sepenuhnya tercapai dikarenakan baik siswa maupun orang tua masih tebang pilih untuk sekolah yang diinginkannya. Beliau menambahkan untuk pelaksanaan sistem zonasi sendiri siswa yang mungkin perasaannya hanya sekedar untuk batu loncatan. Untuk zonasi mempunyai satu, dua, dan tiga pilihan. Ketika pilihan satu di SMA Negeri 1 tidak lulus dan dan pilihan dua di SMA Negeri 4 Kota Bima lulus kemudian pilihan kedua lulus berarti langsung bergeser ke SMA Negeri 4. Hal ini merupakan sebagai batu loncatan karena masih ada beberapa sekolah yang tidak mentaati aturan zonasi. Setelah itu, ketika ingin pindah langsung diberikan surat rekomendasi menerima tanpa mengkonfirmasi dulu ke kepala sekolah yang lain sehingga awalnya seorang siswa yang memang notabenenya dari dulu berkeinginan masuk ke SMA Negeri 1 Kota Bima. Situasi tersebut dimanfaatkan sebagai ajang untuk pindah sekolah. Padahal, ketika sudah diterapkan sistem zonasi harusnya kita bersama-sama mantaati peraturan yang berlaku dengan sebaik-baiknya. Kami berharap jika sistem zonasi ingin dilaksanakan terus dapat dipertegas. Jadi regulasi itu harus bisa kita 
jadikan sebagai bahan acuan supaya tidak ada lagi Kepala Sekolah atau sekolah yang merasa ingin manampung siswa sebanyakbanyaknya. Selain itu, mungkin lebih memperhatikan pemerataan guru.

Menurut Kepala Sekolah SMA Negeri 5 Kota Bima kebijakan zonasi dalam penerimaan siswa baru sudah berjalan selama dua tahun tetapi di tahun pertama masih dalam proses uji coba dan di tahun kedua full menggunakan online. Menurut Sutiati bahwa tujuan pemerintah dengan sistem zonasi sudah bagus dapat memudahkan aksebilitas anakanak bagaimana caranya mendekatkan rumah siswa dengan sekolah. Akan tetapi, mungkin diperlukan penyempurnaan teknik pelaksanaan zonasinya. Khususnya kami di SMA Negeri 5 Kota Bima justru dengan adanya zonasi malah sangat dirugikan. Sedangkan terkait masalah sosialisasi kita telah diberikan sosialisasi. Kami sampai melaksanakan rapat koordinasi beberapa kali di Mataram untuk penetapan zonasi ini.

Penerapan sistem zonasi, secara teknis pendaftaran tidak ada masalah. Hanya saja yang menjadi hambatan di SMA kami sepi peminat. Penyebabnya karena penetapan zona di wilayah Kota Bima ini, dalam satu kelurahan seorang siswa bisa memilih tiga sekolah. Jujur sekolah kami belum dapat bersaing prestasi dengan sekolah yang lain. Itu mungkin animo masyarakat yang masih menganggap rendah SMA Negeri 5 Kota Bima sehingga SMA Negeri 5 banyak dijadikan pilihan kedua dan ketiga sedangkan untuk pilihan pertama hanya beberapa siswa saja.

Di lain sisi, kendala terbesarnya adalah setelah sistem online dibukanya sistem offline. Setelah sistem offline dibuka, sekolah-sekolah favorit kembali mengambil kesempatan untuk merekrut kembali siswa yang terlempar dari pilihan ke dua dan ke tiga dari sekolah. Jadi kita tidak ada keseragaman kata di situ. Untuk mengatasi ini tidak ada upaya yang dilakukan, mau tidak mau kami harus terima kenyataan. Beliau menuturkan, dengan adanya sistem zonasi kami mendapat kuota siswa dalam jumlah yang terbatas sekali. Kami melakukan pemantauan banyak jumlah kelas yang kosong sedangkan yang kami buka sebanyak 10 kelas dan kami hanya mendapatkan 6 kelas sekitar 60 siswa. Hal yang perlu dibenahi, mungkin teknisi penetapan zona itu yang harus dipertimbangkan kembali oleh pemerintah provinsi karena kita berada di bawah naungan provinsi.

Kedua, evaluasi implementasi kebijakan zonasi dilakukan pada lima sekolah yang telah menerapkan sistem zonasi dalam PPDB di Kota Bima. Sekolah tersebut adalah SMA Negeri 1 Kota Bima, SMA Negeri 2 Kota Bima, SMA Negeri 3 Kota Bima, SMA Negeri 4 Kota Bima, dan SMA Negeri 5 Kota Bima. Perhatian utama dalam penelitian ini adalah terletak pada implementasi kebijakan sistem zonasi yang dialami oleh siswa, orang tua siswa dan guru di sekolah. Berikut disajikan data implementasi kebijakan sistem zonasi di Kota Bima yang ditunjukkan pada Tabel 1 .

Tabel 1 menunjukkan bahwa implementasi kebijakan sistem zonasi dalam penerimaan siswa baru dengan responden siswa SMANegeri Kota Bima ada sebanyak 23 siswa (7\%) dalam kategori sangat tinggi, ada sebanyak 155 siswa (46\%) dalam kategori tinggi, ada sebanyak 56 siswa (17\%) dalam kategori sedang, ada sebanyak 83 siswa (24\%) dalam kategori rendah, dan ada sebanyak 22 orang (6\%) dalam kategori sangat rendah. Jika diamati dari hasil di atas, implementasi kebijakan sistem zonasi dalam PPDB melalui responden siswa berada dalam kategori tinggi/baik sebagaimana ditunjukkan oleh tingginya nilai persentase dan skor yang diperoleh.

Selanjutnya analisis dilakukan pada 
Tabel 1

Implementasi Kebijakan sistem Zonasi di Kota Bima berdasarkan

Responden Siswa ditinjau dari Aspek Tata Cara di dalam PPDB

\begin{tabular}{|c|c|c|c|}
\hline Interval & Kriteria & Jumlah & Persentase \\
\hline$X<32,51$ & Sangat rendah & 22 & $6 \%$ \\
\hline $32,51<X \leq 47,34$ & Rendah & 83 & $24 \%$ \\
\hline $47,34<X \leq 54,76$ & Sedang & 56 & $17 \%$ \\
\hline $54,76<X \leq 77,01$ & Tinggi & 155 & $46 \%$ \\
\hline$>77,01$ & Sangat Tinggi & 23 & $7 \%$ \\
\hline \multicolumn{2}{|c|}{ Jumlah } & 339 & $100 \%$ \\
\hline
\end{tabular}

responden orang tua mengenai implementasi kebijakan sistem zonasi di Kota Bima yang ditinjau dari aspek tata cara, rombongan belajar, dan larangan, serta ketentuan lainlain. Berikut ini akan ditampilkan Tabel 2 yang menyajikan hasil analisis masingmasing aspek.

Tabel 2 menunjukkan bahwa implementasi kebijakan sistem zonasi di SMA Negeri Kota Bima dengan responden orang tua yang ditinjau dari aspek tata cara ada sebanyak 16 orang (5\%) dalam kategori tinggi, ada sebanyak 160 orang (47\%) dalam kategori rendah, ada sebanyak 66 orang (19\%) dalam kategori sedang, ada sebanyak 64 orang (19\%) dalam kategori rendah, dan ada sebanyak 33 orang (10\%) dalam kategori sangat rendah. Berdasarkan hasil di atas, implementasi kebijakan sistem zonasi dalam Penerimaan Peserta Didik Baru melalui responden orang tua dilihat dari aspek tata cara berada dalam kategori tinggi/baik.

Gambaran implementasi kebijakan sistem zonasi dengan responden orang tua yang ditinjau dari aspek rombongan belajar akan disajikan pada Tabel 3. Tabel 3 menunjukkan bahwa implementasi kebijakan sistem zonasi melalui responden orang tua yang dilihat dari aspek rombongan belajar dalam kategori tinggi sebanyak 141 orang (42\%), kategori sedang sebanyak 106 orang (31\%), kategori rendah sebanyak 59 orang (17\%), dan kategori sangat rendah sebanyak 33 orang (10\%). Dari hasil di atas dapat diketahui bahwa implementasi kebijakan sistem zonasi dalam PPDB melalui responden orang tua yang ditinjau dari aspek rombongan belajar berada dalam kategori tinggi/baik.

Selanjutnya hasil anlasis implementasi

Tabel 2

Aspek Tata Cara tentang Implementasi Kebijakan sistem Zonasi Berdasarkan Responden Orang Tua

\begin{tabular}{lccc}
\hline \multicolumn{1}{c}{ Interval } & Kriteria & Jumlah & Persentase \\
\hline $\mathrm{X}<47,43$ & Sangat rendah & 33 & $10 \%$ \\
$47,43<\mathrm{X} \leq 63,82$ & Rendah & 64 & $19 \%$ \\
$63,82<\mathrm{X} \leq 72,01$ & Sedang & 66 & $19 \%$ \\
$72,01<\mathrm{X} \leq 96,59$ & Tinggi & 160 & $47 \%$ \\
$>96,59$ & Sangat Tinggi & 16 & $5 \%$ \\
\hline & & 339 & $100 \%$ \\
\hline
\end{tabular}


Tabel 3

Implementasi Kebijakan sistem Zonasi Berdasarkan Responden Orang Tua dengan Aspek Rombongan Belajar

\begin{tabular}{llcc}
\hline \multicolumn{1}{c}{ Interval } & \multicolumn{1}{c}{ Kriteria } & Jumlah & Persentase \\
\hline$X<0,89$ & Sangat rendah & 33 & $10 \%$ \\
$0,89<X \leq 2,60$ & Rendah & 59 & $17 \%$ \\
$2,60<X \leq 4,31$ & Sedang & 106 & $31 \%$ \\
$4,31<X \leq 6,02$ & Tinggi & 141 & $42 \%$ \\
$>6,02$ & Sangat tinggi & 0 & $0 \%$ \\
\hline \multicolumn{2}{c}{ Jumlah } & 339 & $100 \%$ \\
\hline
\end{tabular}

kebijakan sistem zonasi dalam PPDB dengan responden orang tua yang ditinjau dari aspek larangan dan ketentuan lain-lain dapat disajikan pada Tabel 4.

Berdasarkan Tabel 4 dapat diketahui bahwa implementasi kebijakan sistem zonasi dalam PPDB di Kota Bima dengan responden orang tua yang ditinjau dari aspek larangan dan ketentuan lain-lain ada sebanyak 221 orang $(65 \%)$ dalam kategori tinggi, sebanyak 60 orang $(18 \%)$ dalam kategori sedang, sebanyak 31 orang (9\%) dalam kategori rendah, dan ada sebanyak 27 orang $(8 \%)$ dalam kategori sangat rendah. Dari hasil di atas menunjukkan bahwa implementasi kebijakan sistem zonasi dalam PPDB melalui responden orang tua yang di tinjau dari aspek larangan dan ketentuan lain-lain berada pada kategori tinggi/baik.

Selanjutnya akan dilihat dari implementasi kebijakan sistem zonasi berdasarkan pengalaman guru di SMANegeri Kota Bima yang ditinjau dari aspek tata cara, rombongan belajar, laporan dan pengawasan, dan larangan dan ketentuan lain-lain. Hasil analisis disajikan pada Tabel 5 .

Tabel 5 menunjukkan bahwa implementasi kebijakan sistem zonasi dalam Penerimaan Peserta Didik Baru dengan responden guru yang dilihat dari aspek tata cara ada 106 orang (54\%) dalam kategori tinggi, sebanyak 37 orang $(19 \%)$ dalam kategori sedang, sebanyak 31 orang (16\%) dalam kategori rendah, dan ada sebanyak 21 orang $(11 \%)$ kategori sangat rendah. Berdasarkan hasil di atas dapat dilihat bahwa implementasi kebijakan sistem zonasi di Kota Bima dengan responden guru berada dalam kategori tinggi/baik.

Implementasi kebijakan sistem zonasi dalam PPDB di Kota Bima dengan responden guru yang ditinjau dari aspek

Tabel 4

Aspek Larangan dan Ketentuan dan lain-lain tentang Implementasi Kebijakan Sistem Zonasi Berdasarkan Responden Orang Tua

\begin{tabular}{|c|c|c|c|}
\hline Interval & Kriteria & Jumlah & Persentase \\
\hline$X<2,81$ & Sangat rendah & 27 & $8 \%$ \\
\hline $2,81<X \leq 3,85$ & Rendah & 31 & $9 \%$ \\
\hline $3,85<X \leq 4,89$ & Sedang & 60 & $18 \%$ \\
\hline $4,89<X \leq 5,93$ & Tinggi & 221 & $65 \%$ \\
\hline$>5,93$ & Sangat Tinggi & 0 & $0 \%$ \\
\hline \multicolumn{2}{|c|}{ Jumlah } & 339 & $100 \%$ \\
\hline
\end{tabular}


Tabel 5

Aspek Tata Cara tentang Implementasi Kebijakan Sistem Zonasi Berdasarkan Responden Guru

\begin{tabular}{lccc}
\hline \multicolumn{1}{c}{ Interval } & Kriteria & Jumlah & Persentase \\
\hline $\mathrm{X}<61,71$ & Sangat rendah & 21 & $11 \%$ \\
$61,71<\mathrm{X} \leq 75,39$ & Rendah & 31 & $16 \%$ \\
$75,39<\mathrm{X} \leq 82,24$ & Sedang & 37 & $19 \%$ \\
$82,24<\mathrm{X} \leq 102,76$ & Tinggi & 106 & $54 \%$ \\
$>102,76$ & Sangat Tinggi & 0 & $0 \%$ \\
\hline & & 195 & $100 \%$ \\
\hline
\end{tabular}

rombongan belajar akan disajikan pada Tabel 6.

Tabel 6 menunjukkan bahwa implementasi kebijakan sistem zonasi dalam PPDB di SMA Negeri Kota Bima melalui responden orang tua yang ditinjau dari aspek rombongan belajar ada sebanyak 95 orang $(49 \%)$ dalam kategori tinggi, sebanyak 65 orang $(33 \%)$ dalam kategori sedang, sebanyak 11 orang $(6 \%)$ dalam kategori rendah, ada sebanyak 24 orang (12\%) dalam kategori sangat rendah. Hal ini menunjukkan bahwa implementasi kebijakan sistemm zonasi dalam PPDB dengan responden guru yang ditinjau dari aspek rombongan belajar berada dalam kategori tinggi/baik.

Implementasi kebijakan sistem zonasi dalam PPDB di Kota Bima melalui responden guru yang ditinjau dari aspek laporan dan pengawasan akan disajikan pada Tabel 7. Tabel 7 menunjukkan bahwa implementasi kebijakan sistem zonasi dalam PPDB melaui responden guru yang ditinjau dari aspek laporan dan pengawasan dalam kategori tinggi sebanyak 106 orang (54\%), kategori sedang sebanyak 51 orang (26\%), kategori rendah sebanyak 22 orang $(11 \%)$, dan dalam katgeori sangat rendah sebanyak 16 orang $(8 \%)$. Hal ini menujukkan bahwa implementasi kebijakan sistem zonasi dalam PPDB di SMA Negeri Kota Bima melalui responden guru dilihat dari aspek laporan dan pengawasan berada dalam kategori tinggi/baik.

Implementasi kebijkan sistem zonasi dalam PPDB di SMA Negeri Kota Bima dengan responden guru yang dilihat dari aspek larangan dan ketentuan lain-lain akan disajikan pada Tabel 8.

Tabel 6

Aspek Rombongan Belajar tentang Implementasi Kebijakan Sistem Zonasi Berdasarkan Responden Guru

\begin{tabular}{lccc}
\hline \multicolumn{1}{c}{ Interval } & Kriteria & Jumlah & Persentase \\
\hline $\mathrm{X}<6,26$ & Sangat rendah & 24 & $12 \%$ \\
$6,26<\mathrm{X} \leq 7,91$ & Rendah & 11 & $6 \%$ \\
$7,91<\mathrm{X} \leq 9,55$ & Sedang & 65 & $33 \%$ \\
$9,55<\mathrm{X} \leq 11,194$ & Tinggi & 95 & $49 \%$ \\
$>11,194$ & Sangat Tinggi & 0 & $0 \%$ \\
\hline & & 195 & $100 \%$ \\
\hline
\end{tabular}


Tabel 7

Aspek Laporan dan Pengawasan tentang Implementasi Kebijakan Sistem Zonasi

Berdasarkan Responden Guru

\begin{tabular}{lccc}
\hline \multicolumn{1}{c}{ Interval } & Kriteria & Jumlah & Persentase \\
\hline $\mathrm{X}<2,75$ & Sangat rendah & 16 & $8 \%$ \\
$2,75<\mathrm{X} \leq 3,75$ & Rendah & 22 & $11 \%$ \\
$3,75<\mathrm{X} \leq 4,75$ & Sedang & 51 & $26 \%$ \\
$4,75<\mathrm{X} \leq 5,75$ & Tinggi & 106 & $54 \%$ \\
$>5,75$ & & 0 & $0 \%$ \\
\hline & Sangat Tinggi & 195 & $100 \%$ \\
\hline
\end{tabular}

Tabel 8

Aspek Larangan dan Ketentuan lain-lain tentang Implementasi Kebijakan

Sistem Zonasi Berdasarkan Responden Guru

\begin{tabular}{|c|c|c|c|}
\hline Interval & Kriteria & Jumlah & Persentase \\
\hline$X<4,89$ & Sangat rendah & 14 & $7 \%$ \\
\hline $4,89<\mathrm{X} \leq 7,07$ & Rendah & 49 & $25 \%$ \\
\hline $7,07<X \leq 9,25$ & Sedang & 45 & $23 \%$ \\
\hline $9,25<\mathrm{X} \leq 11,44$ & Tinggi & 87 & $45 \%$ \\
\hline$>11,44$ & Sangat Tinggi & 0 & $0 \%$ \\
\hline \multicolumn{2}{|c|}{ Jumlah } & 195 & $100 \%$ \\
\hline
\end{tabular}

Tabel 8 menunjukkan bahwa implementasi kebijkan sistem zonasi dalam PPDB di SMA Negeri Kota Bima dengan rseponden guru yang ditinjau dari aspek larangan dan ketentuan dan lain-lain ada sebanyak 87 orang $(45 \%)$ dalam kategori tinggi, sebanyak 45 orang (23\%) dalam kategori sedang, sebanyak 49 orang (25\%) dalam kategori rendah, dan ada sebanyak 14 orang (7\%) dalam kategori sangat rendah. Hal ini menunjukkan bahwa implementasi kebijakan sistem zonasi dalam Penerimaan Peserta Didik Baru dengan responden guru menunjukkan yang dilihat dari aspek larangan dan ketentuan lain-lain berada dalam kategori tinggi/baik.

Kedua, konsep zonasi pada dasarnya dengan tujuan mendekatkan siswa dengan sekolah sehingga nilai Ujian Nasional bukan menjadi prioritas utama agar diterima di sekolah yang diinginkan. Oleh karena itu, akan dilihat nilai rata-rata Ujian Nasional sebagai bahan pembanding mulai tahun 2017-2019 (Tabel 9).

Berdasarkan nilai rata-rata Ujian Nasional SMP siswa dari tahun 2016-2019 pada Tabel 9 dapat disimpulkan bahwa implementasi kebijakan sistem zonasi dalam PPDB di SMA Negeri di Kota Bima secara keseluruhan sudah terlaksana dengan baik di dalam mencapai tujuannya. Hal tersebut terbukti dengan adanya perubahan nilai rata-rata ujian nasional siswa SMP yang mendaftar di SMA Negeri kota dari tahun ke tahun.

Pembahasan pada penelitian ini menyajikan hasil evaluasi implementasi kebijkan sistem zonasi dalam PPDB di SMA Negeri di Kota Bima. Pertama, tanggapan kepala sekolah terhadap implementasi 
Tabel 9

Nilai Rata-rata Ujian Nasional SMP 2016/2017, 2017/2018, dan 2018/2019

\begin{tabular}{ccccc}
\hline \multirow{2}{*}{ No } & \multirow{2}{*}{ Nama Sekolah } & \multicolumn{3}{c}{ Rata-rata } \\
\cline { 3 - 5 } & & $2016 / 2017$ & $2017 / 2018$ & $2018 / 2019$ \\
\hline 1 & SMAN 1 KOBI & 59,22 & 49,65 & 46,78 \\
2 & SMAN 2 KOBI & 45,02 & 44,65 & 42,23 \\
3 & SMAN 3 KOBI & 42,18 & 38,89 & 37,21 \\
4 & SMAN 4 KOBI & 48,91 & 44,48 & 41,98 \\
5 & SMAN 4 KOBI & 42,63 & 44,76 & 38,99 \\
\hline
\end{tabular}

kebijakan zonasi dalam PPDB di Kota Bima secara umum sangat positif, namun ada beberapa kesulitan antara lain: penetapan zona, sekolah yang berada dalam naungan Dinas pendidikan dan Kebudayaan dan sekolah yang berada dalam naungan Departemen Agama tidak secara serentak membuka PPDB, penyebaran guru-guru di sekolah yang belum meratakemudian, kurangnya episentrum hukum yang mengatur tentang kebijakan sistem zonasi dalam PPDB yang dapat meunimbulkan terjadinya rawan pada tindak kecurangan dan ketidakadilan.

Kedua, implementasi kebijakan sistem zonasi dalam penerimaan siswa baru di kota bima menunjukkan bahwa implementasi kebijakan sistem zonasi dalam PPDB dikategorikan tinggi dengan menggunakan siswa orang tua, dan guru sebagai responden. Hal ini terlihat dari hasil penelitian dengan variabel Peraturan pemerintah No.17 tahun 2017 tentang sistem zonasi dalam PPDB yang terlihat di lima sekolah dijadikan sampel yang telah menerapkan sistem zonasi.

Ketiga, hasil implementasi kebijakan sistem zonasi dalam penerimaan peserta didik baru adalah prestasi yang ditinjau dari nilai ujian nasional yang mendaftar di SMA Negeri terlaksana dengan. Hal ini terlihat perubahan menurunnya nilai ratarata ujian nasional dari tahun ke tahun yang menunjukkan bahwa implementasi sistem zonasi telah merata.

\section{SIMPULAN}

Berdasarkan hasil analisis data, dan pembahasan dapat ditarik kesimpulan sebagai berikut. Pertama, implementasi kebijakan sistem zonasi dalam PPDB berdasarkan hasil wawancara dengan Kepala sekolah tanggapannya sangat positif dan telah berjalan dengan baik. Namun, ada beberapa kendala antara lain: regulasi penetapan zonasi (jarak antara rumah dengan sekolah jelas), sosialisasi mengenai zonasi perlu ditingkatkan, sekolah yang berada dalam naungan Departemen Pendidikan dan Kebudayaan dan sekolah yang berada dalam naungan Departemen Agama tidak berjalan secara serentak di dalam melakukan pembukaan pendaftaran siswa baru, penyebaran guru yang belum merata di sekolah, dan tidak adanya epinstrum hukum yang kuat yang mengatur tentang sistem zonasi. Kedua, proses Implementasi Kebijakan sistem zonasi dalam PPDB di SMA Negeri Kota Bima berdasarkan responden siswa, orang tua, dan guru berada dalam kategori tinggi/baik. Hal ini menunjukkan implementasi kebijakan zonasi di SMA Negeri Kota Bima telah berjalan dengan baik. Ketiga, tujuan kebijakan sistem zonasi dalam PPDB yang ditinjau dari nilai rata-rata ujian nasional (UN) siswa telah 
merata. Hal tersebut ditunjukkan dengan adanya perubahan penurunan nilai ratarata Ujian Nasional dari tahun ke tahun. Dengan demikian membuktikan bahwa dengan sistem zonasi menyebabkan siswa berprestasi tidak menumpuk pada sekolah tertentu tetapi menyebar ke semua sekolah.

\section{DAFTAR PUSTAKA}

Adiputra, A. R., Karsidi, R., \& Haryono, B. (2019). Cultural lag dalam program penerimaan peserta didik baru (PPDB) online dengan sistem zonasi tahun 2018 di Sekolah Menengah Atas Negeri 2 Sukoharjo. Habitus: Jurnal Pendidikan, Sosiologi, dan Antropologi, 3(1), 1-13. Diunduh dari https://jurnal.uns.ac.id/ habitus/issue/view/2364.

Azwar, S. (2018). Penyusunan skala psikologi. Yogyakarta: Pustaka Pelajar.

Álvarez, B., \& Ruiz-Casares, M. (1998). Evaluation and educational reform: Policy options. USAID, Bureau for Latin America and the Caribbean, Office for Regional Sustainable Development, Education and Human Resources Division.

Bintoro, R. F. A. (2018). Persepsi masyarakat terhadap implementasi kebijakan zonasi sekolah dalam penerimaan peserta didik baru (PPDB) tingkat SMA tahun ajaran 2017/2018 di Kota Samarinda. Jurnal Riset Pembangunan, 1(1), 48-57. Diunduh dari https://jurnal.unigal.ac.id/ index.php/dinamika/article/view/1737.

Eto, Y. (2015). Education or tool for social stratification? Diunduh dari http://www.semanticscholar.org/ paper/Education-or-tool-for-socialstratification Eto/948b558bcd968839c 963c0a6d41754b8a587f937.

Musset, P. (2012). School choice and equity: Current policies in OECD countries and a literature review. Diunduh dari https:// dx.doi.org/10.1787/5k9fq23507vc-en.
Maloutas, T., Hadjiyanni, A., Kapella, A., Spyrellis, S. N., \& Valassi, D. (2013, August). Education and social reproduction: The impact of social origin, school segregation and residential segregation on educational performance in Athens. Dalam RC21 (ISA) Conference on Resourceful Cities (pp. 29-31). Berlin, Germany

Narayan, A., Saavedra-Chanduvi, J., \& Tiwari, S. (2013). Shared prosperity: Links to growth, inequality and inequality of opportunity. Policy Research Working Paper. Diunduh dari https://openknowledge.worldbank. org/handle/10986/16866.

Perdana, N. S. (2019). Implementasi PPDB zonasi dalam upaya pemerataan akses dan mutu pendidikan. Jurnal Pendidikan Glasser, 3(1), 78-92. Diunduh dari http:// lonsuit.unismuhluwuk.ac.id/index.php/ glasser/article/viewFile/186/125.

Sirozi, M. (2010). Politik pendidikan. Jakarta: PT. Raja Grafindo.

Seknun, M. Y. ( 2015). Pendidikan sebagai media mobilitas sosial. Jurnal UIN Aluddin, 2(1),131-144. Diunduh dari journal.uinalauddin.ac.id/index.php/ auladuna/article/download/872/843.

Syamsuriyanti, \& Sukirno. (2018). Faktor determinan profesionalisme guru. Jurnal Kependidikan, 2(1), 56-67. Diunduh dari https://journal.uny.ac.id/ index.php/jk/article/view/10588/pdf.

Tilaar, H. A. R. (2001). Manajemen pendidikan nasional. Bandung: PT. Remaja Rosdakarya.

$\mathrm{Wu}, \mathrm{X}$. (2017). Higher education, elite formation and social stratification in contemporary China: Preliminary findings from the Beijing college students panel survey. Chinese Journal of Sociology, 3(1), 3-31. Diunduh dari https://doi. org/10.1177/2057150X16688144. 